\title{
Histological and Molecular Classification of Chronic Myeloproliferative Disorders in the Age of JAK2: Persistence of Old Questions despite New Answers
}

\author{
Kais Hussein Oliver Bock Hans Kreipe \\ Institute of Pathology, Hannover Medical School, Hannover, Germany
}

\begin{abstract}
Key Words
Chronic myeloproliferative disorders $\cdot$ Classification Janus kinase 2
\end{abstract}

\begin{abstract}
The discovery of the Janus kinase 2 gain-of-function V617F mutation $\left(J A K 2^{\mathrm{V} 617 \mathrm{~F}}\right)$ provided a major breakthrough in the understanding of Philadelphia chromosome-negative chronic myeloproliferative disorders ( $\left.\mathrm{Ph}^{-} \mathrm{CMPD}\right)$. Among haematologic neoplasm the mutation appears to be almost specific for $\mathrm{Ph}^{-} \mathrm{CMPD}$ but the different entities comprising polycythaemia vera (PV), essential thrombocythaemia and chronic idiopathic myelofibrosis (CIMF) are not discriminated by the mutation. It is unclear how the diversity with heterogeneous clinical and pathoanatomical presentations comes about. It has been suggested that differences in JAK2 ${ }^{\mathrm{V} 617 \mathrm{~F}}$ gene dosage or different degrees to which the haematologic lineages are affected by the mutation could explain the heterogeneity of morphology and prognosis. Indeed the mutation mediates a PV-like phenotype but with regard to myelofibrosis JAK2 ${ }^{\mathrm{V} 617 \mathrm{~F}}$ does not appear to be a causative factor. Megakaryocytes are homozygous in the majority of fibrotic CIMF and PV, whereas JAK2 $2^{\mathrm{V} 617 \mathrm{~F}}$ heterozygosity is predominantly encountered in prefibrotic CIMF and essential thrombocythaemia but transition from hetero- to homozygosity with onset of fibrosis is rare. In conclu-
\end{abstract}

\section{KARGER}

Fax +41613061234

E-Mail karger@karger.ch

www.karger.com (c) 2007 S. Karger AG, Basel

$1015-2008 / 07 / 0742-0072 \$ 23.50 / 0$

Accessible online at:

www.karger.com/pat sion, JAK2 ${ }^{\mathrm{V} 617 \mathrm{~F}}$ provides a valuable adjunct to the diagnosis of $\mathrm{Ph}^{-} \mathrm{CMPD}$, in particular with regard to discrimination from reactive proliferations, but the challenge of correct subtyping and hence prognostication persists for clinicians and bone marrow pathologists.

Copyright $\odot 2007$ S. Karger AG, Basel

\section{Introduction}

Chronic myeloproliferative disorders (CMPD) represent clonal proliferations of a pathological haematopoietic stem cell (HSC) and affect all or a subset of the haematopoietic lineages, resulting in a mono-, bi- or trilinear proliferation of megakaryocytic, erythroid and granulocytic precursor cells. CMPD encompass chronic myeloid leukaemia (CML), polycythaemia vera (PV), essential thrombocythaemia (ET) and chronic idiopathic myelofibrosis (CIMF; synonymously also chronic megakaryocytic granulocytic myelosis, myelofibrosis with myeloid metaplasia or agnogenic myeloid metaplasia). Chronic neutrophilic leukaemia and chronic eosinophilic leukaemia represent rare forms of CMPD [1].

Recognized at an early date [2], the CMPD were grouped together as a closely related set of haematologic disorders by Dameshek $[3,4]$ but the pathogenesis remained a mystery. Despite overlap in clinical presenta- 
tion, there are distinct morphological features which enable subtyping of CMPD in most instances. CMPD entities are characterized by altered bone marrow histology with a mono- to trilinear sustained proliferation and cellular atypia, the latter predominantly affecting megakaryocytes. Facultative changes are marrow fibrosis, blast increase and cytogenetic abnormalities. Clinical criteria used for subtyping by the Polycythemia Vera Study Group [5] comprise enhanced blood cell counts, anaemia and organomegaly of the liver and spleen induced by extramedullary haematopoiesis. Complications may be caused by thrombotic events, haemorrhagic diatheses and constitutional weakness, and major inauspicious prognostic factors are blastic transformation into acute myeloid leukaemia (AML), severe myelofibrosis, portal hypertension and infection.

\section{Challenges in Subtyping of Philadelphia Chromosome-Negative CMPD (PV, ET and CIMF)}

Typical bone marrow histology in PV displays prominent proliferation of all haematopoietic cell lineages with increase in erythropoiesis as well as granulopoiesis and almost complete erasure of fatty tissue. In early stages, the hypercellularity may not be as prominent with a considerable amount of preserved fat cells and a predominant megakaryocytic proliferation. In these cases discrimination from ET may pose a severe problem which can only be resolved by follow-up observation [6]. In the so-called spend phase or post-PV myelofibrosis with progressed bone marrow fibrosis, distinction from fibrotic CIMF may be impossible on morphological grounds alone.

Another challenge encountered when classifying CMPD is the prediction of fibrotic progression in thrombocytotic proliferations. A thrombocytosis without fibrotic risk is defined as ET and characterized by loose clusters of enlarged to giant megakaryocytes with hyperploid nuclei, but no increase in cellularity with normal erythropoiesis and granulopoiesis, and no reticulin fibrosis [1]. Cellular CIMF, which by contrast carries a higher risk of evolvement to myelofibrosis, is indistinguishable on clinical grounds from ET. This type of ETlike thrombocytosis is considered as an early stage of CIMF and hence categorized as prefibrotic or cellular CIMF because both disorders share atypical giant to medium-sized megakaryocytes with bulbous, cloud-like nuclei, and follow-up studies provided evidence for the progression of cellular to fibrotic CIMF over time [7]. In a considerable proportion of cases, clear-cut differentiation of ET from prefibrotic CIMF may be very difficult even for experienced bone marrow histopathologists. Furthermore, prefibrotic CIMF cases exhibit tremendous variability with regard to the duration of the stable phase before progression to fibrosis occurs, ranging from a few months to decades.

\section{Molecular Markers for CMPD}

Recent years have brought about considerable progress in our understanding of the molecular events which give rise to CMPD. From these insights valuable markers have emerged which provide an indispensable adjunct in diagnosis finding. Almost 20 years ago a CML-specific molecular alteration was identified, characterized by the expression of the chimeric fusion protein BCR/ABL which results from the Philadelphia chromosome translocation $\mathrm{t}(9 ; 22)$. Since that time CMPD have been subdivided into $\mathrm{t}(9 ; 22)(\mathrm{q} 34 ; \mathrm{q} 11) \mathrm{BCR} / \mathrm{ABL}$ fusion gene/Philadelphia chromosome-positive $\left(\mathrm{Ph}^{+}\right)[8,9]$ and Philadelphia chromosome-negative $\left(\mathrm{Ph}^{-}\right)$disorders. Another milestone was achieved with the most recently discovered $1849 \mathrm{G}>\mathrm{T}$ mutation in exon 12 of the Janus tyrosine kinase (JAK) 2 gene [10-17]. This hot spot point mutation is located on chromosome $9 \mathrm{p}$ and leads to a gain of function due to a defective valine-to-phenylalanine exchange at the amino acid position 617 (V617F) of the autoinhibitory JH2 pseudokinase domain of JAK2. Thus the mutated JAK $2^{\mathrm{V} 617 \mathrm{~F}}$ tyrosine kinase is constitutively activated and conveys erythropoietin (EPO) hypersensitivity and growth factor independence to transfected cell lines. After antecedent irradiation, transplantation of JAK $2^{\mathrm{V} 617 \mathrm{~F}_{-}}$ transfected cells was sufficient to mimic human PV [10, $18,19]$ and its evolution towards myelofibrosis $[18,19]$ in murine in vivo models. Interestingly, already in 1997 a gain of function point mutation of the Drosophila melanogaster $\mathrm{JH} 2$ homologue was linked to a leukaemia-like aberrant haematopoiesis [20] and in 1999 an unsuccessful systematic search for a putative alteration in the JH2 domain of JAK2 was performed in patients suffering from myelodysplastic syndromes (MDS), CML, AML and acute lymphoblastic leukaemia, but not $\mathrm{Ph}^{-} \mathrm{CMPD}$ [21].

In a systematic study, a panel of 79 cell lines representing CMPD, MDS, AML and acute lymphoblastic leukaemia was analysed for the JAK2 status, and CMPD/MDSderived MB-02, MUTZ-8, UKE-1 and SET-2 as well as erythroleukaemia-derived HEL were positive for the mu- 
tation. Among them, only SET-2 proved to be heterozygous for the mutation, while the other 4 cell lines displayed homozygosity [22]. In clinical samples, $\mathrm{Ph}^{-} \mathrm{CMPD}$ were affected by the mutation, whereas other myeloid malignancies only exceptionally revealed the mutation $[16,17,23-28]$ and $\mathrm{Ph}^{+} \mathrm{CML}$, lymphoid malignancies and non-neoplastic haematopoiesis lack the JAK2 mutation completely [17, 29, 31].

The gain of function mutation in JAK2 $2^{\mathrm{V} 617 \mathrm{~F}}$ affects the JAK/STAT cellular signal transduction pathway. Via cytokine-mediated receptor stimulation, signal transducers and activators of transcription (STAT) are activated through JAK-mediated tyrosine phosphorylation. This leads to STAT dimerization, nuclear translocation and regulation of target gene expression by several downstream effectors.

The aberrant JAK2 ${ }^{\mathrm{V} 617 \mathrm{~F}} / \mathrm{STAT} 5$ signal cascade is hypersensitive to EPO [10,29], thrombopoietin (TPO), interleukin-3 [15] and granulocyte colony-stimulating factor (G-CSF) [32]. In the myeloid lineages, the gain of function is essentially dependent on related type I cytokine receptors for EPO, G-CSF and TPO [33]. Paradoxically, some cytokines may also have inhibitory effects for yet unknown reasons. In vitro culturing of $\mathrm{CD} 34^{+}$cells derived from peripheral blood of mutated PV patients showed that increased EPO levels resulted in decreased survival of the JAK2 ${ }^{\mathrm{V} 617 \mathrm{~F}}$ clone [34]. Compensatory negative regulating feedback mechanisms of JAK/STAT, particularly suppressors of cytokine signalling (SOCS), may react to this EPO hyperstimulation and constitutively activated JAK2 ${ }^{\mathrm{V} 617 \mathrm{~F}}$. While this particular question is largely unsettled, it has been demonstrated that G-CSF stimulation in JAK2 ${ }^{\mathrm{V} 617 \mathrm{~F}}$ CMPD patients did not have any significant influence on SOCS-3 expression [32]. Referring to this, SOCS-1 is overexpressed in PV, CIMF and ET but did not correlate with the underlying JAK2 mutation, probably reflecting a JAK2 ${ }^{\mathrm{V} 617 \mathrm{~F}}$-independent general negative feedback mechanism against autonomous proliferation in all $\mathrm{Ph}^{-} \mathrm{CMPD}$ subtypes [35]. Furthermore, we investigated Friend leukaemia integration-1 (Fli-1) expression, which is involved in lineage commitment of megakaryocytes and myeloid progenitors through induction of JAK, and we could demonstrate that Fli-1 expression levels were significantly elevated in JAK2 ${ }^{\mathrm{V} 617 \mathrm{~F}}$ ET [36]. However, in other $\mathrm{Ph}^{-}$ CMPD entities the mutation status per se showed no influence on the Fli-1 expression [36]. These findings indicate the absence of a simple up and down regulatory mechanism and suggest a hidden complex control cascade.
In the first descriptions of the JAK2 $2^{\mathrm{V} 617 \mathrm{~F}}$ mutation, it was believed that only the myeloid lineage was affected $[10-17,29,37]$, although lymphoid involvement was not precluded [9]. Recent findings in PV and CIMF indicate that in fact the mutation is acquired at the putative earliest level, namely in the pluripotent HSC [34, 38, 39]. In order to characterize the HSC in JAK2 ${ }^{\mathrm{V} 617 \mathrm{~F}}$-mutated PV, CD34-positive HSC were selected and expanded in an in vitro differentiation assay. Differentiating HSC did not transmit the mutation to all haematopoietic lineages. Whereas granulocytes and megakaryocytes/platelets carried the molecular defect, precursor $\mathrm{B}$ and $\mathrm{T}$ cells and mature $\mathrm{CD}_{1} 9^{+} \mathrm{B}$ and $\mathrm{CD} 3^{+} \mathrm{T}$ lymphocytes were affected only in a minor subset of PV and CIMF samples, or solely B lymphocytes belonged to the JAK $2^{\mathrm{V} 617 \mathrm{~F}}$ clone [34, 39]. Interestingly, the frequency of mutated JAK 2 allele was observed to be 3 times lower in B cells and about 12 times lower in T cells than in $\mathrm{CD} 34^{+}$and myeloid cells [34], indicating a proliferation disadvantage for the JAK2 ${ }^{\mathrm{V} 617 \mathrm{~F}}$ lymphoid cells. Thus it is most likely that the mutation affects an aberrant HSC, but with regard to the absent or very low allele frequency in lymphocytes, only a minority of lymphoid precursor cells reach maturation. Accordingly, lymphocytes do not express the adequate receptors providing the first link in the chain between JAK2 ${ }^{\mathrm{V} 617 \mathrm{~F}} / \mathrm{STAT}$ and downstream intracellular signal transduction [32]. Referring to this, the clinical relevance of lymphocytic clonal involvement remains doubtful and until now no JAK2 $2^{\mathrm{V} 617 \mathrm{~F}}$-genuine lymphoid malignancy [15-17] has been reported. Even in a case of pre-existing JAK2 ${ }^{\mathrm{V} 617 \mathrm{~F}} \mathrm{PV}$ a succeeding lymphoid neoplasm did not originate from the same clone [40].

In rare cases the mutation might possibly be acquired at different levels other than HSC, after the segregation of the myeloid lineages. It has been shown that in PV solely the erythroid lineage can harbour the mutation [41] while in ET predominantly megakaryocytes can be affected [42].

Very recently, a systematic search for genetic aberrations in haematopoietic-specific cytokine receptors in $\mathrm{Ph}^{-} \mathrm{CMPD}$ revealed in about 5-9\% of ET and CIMF patients another gain of function point mutation in the thrombopoietin receptor $\left(\mathrm{MPL}^{\mathrm{W} 515 \mathrm{~L}}\right.$ or $\left.\mathrm{MPL}^{\mathrm{W} 515 \mathrm{~K}}\right)[43$, 44]. Interestingly, most of the MPL-mutated cases had a JAK2 wild-type status, but a few cases carried MPL ${ }^{\text {W515L }}$ and JAK2 ${ }^{\mathrm{V} 617 \mathrm{~F}}$ concurrently [44]. The relevance for diagnostic purposes particularly in JAK2 wild-type $\mathrm{Ph}^{-}$ CMPD and therapeutical consequences remain to be further evaluated. 


\section{Methods for the Analysis of JAK2 ${ }^{\mathrm{V} 617 F}$}

Usually, the detection of JAK2 mutation is technically undemanding and reliable, but the costs of devices and methods range from relatively cheap to expensive. For diagnostic and research purposes, DNA and RNA/cDNA can be obtained from peripheral blood (mononuclear cell fraction, granulocytes, platelets and flow-cytometrical fractioned cells), formalin-fixed and paraffin-embedded bone marrow trephines or bone marrow-derived laser microdissected cells, such as megakaryocytes [10-17, 30, 31, 42]. Even solid organ tissues, such as liver biopsies showing extramedullar haematopoiesis, are suitable for JAK2 detection (own unpublished data).

The JAK2 status can be expressed in different ways, either simply as mutated/unmutated, as wild-type/heterozygous/homozygous or as the gene dosage/allele frequency of the percentage of mutated G $>$ T allele. It should be taken into account that the JAK2 status can be changed by intermingled stromal cells, e.g. bone marrow fibrocytes, and/or other polyclonal JAK2 wild-type cells, such as lymphocytes. Different methods can be used to detect the $1849 \mathrm{G}>\mathrm{T}$ transition in DNA and/or cDNA. A well known and simple to use detection method for single nucleotide polymorphisms (SNP) are restriction enzymes. The BasX I restriction enzyme is suitable for digestion of the wild-type JAK2 polymerase chain reaction (PCR) product, but fails to recognize the mutant $\mathrm{G}>\mathrm{T}$ hot spot, leaving the PCR product unfragmented [11, 17]. Amplification refractory mutation system (ARMS) assay is based on a tetra-primer JAK2-PCR, consisting of 2 primer pairs for the simultaneous amplification of the wildtype and mutated SNP alleles [11]. Both assays have the advantage of employing only standard PCR devices and some specific reagents. Pyrosequencing ${ }^{\circledR}$ is based on a luciferase-dependent light signal, which is proportional to pyrophosphate release for every incorporated nucleotide at the SNP hot spot. Apart from pyrosequencing [16], real-time PCR-based assays $[17,29,45]$ and capillary electrophoresis $[10,14]$ also allow a quantification of the ratio of wild-type $\mathrm{G}$ to mutant $\mathrm{T}$ allele. Of note, primer sequences and product lengths may vary between different publications without affecting the overall result. Actually, a systematic comparison of all available methods has not been done so far, but for validation reasons the generated JAK2-PCR products are often used for more than one method. For example, ARMS assay and BsaX I restriction analysis can be combined if requested [11].

Interestingly, we (unpublished data) and others [12, 34] observed that in the same sample the percentage of mutated $\mathrm{T}$ allele is constantly higher in cDNA than genomic DNA. Whether the mutant allele might have a transcriptional advantage or whether JAK2-mutated mRNA is more stable than the wild-type form remains to be resolved. However, this implies the use of cDNA for diagnostic purpose, which might be more sensitive.

\section{Detection of JAK2 ${ }^{\mathrm{V} 617 F}$ in Bone Marrow Trephines}

Unlike the BCR/ABL junction, the JAK2 $2^{\mathrm{V} 617 \mathrm{~F}}$ abnormality in CMPD exhibits 2 peculiar features: (1) it is not specific for one type of CMPD but occurs at different frequencies in all $\mathrm{Ph}^{-} \mathrm{CMPD}$ and (2) although $\mathrm{Ph}^{-} \mathrm{CMPD}$ provide clonal proliferations, the JAK2 ${ }^{\mathrm{V} 617 \mathrm{~F}}$ aberration is neither present in all non-lymphoid lineages and nor in all cells of one identical lineage.

With regard to the first issue, a number of studies have shown that all $\mathrm{Ph}^{-} \mathrm{CMPD}$ subtypes may be affected by mutated JAK2 ${ }^{\mathrm{V} 617 \mathrm{~F}}$, the highest rate occurring in PV (65$97 \% ; 21-70 \%$ homozygous), whereas variable proportions were found in CIMF (35-95\%, 9-22\% homozygous) and ET ( $23-75 \%, 0-6 \%$ homozygous) [10-17, 23-31, 46$48,50]$. For a detailed summary of mutation frequencies in different myeloid and lymphoid entities see table 1. Because the variability of findings could be due to different classification schemes of CMPD, we performed an investigation on more than 340 bone marrow trephines exhibiting typical CMPD classified according to the WHO, including 79 previously published cases [31]. In this ongoing study more than $95 \%$ of PV were positive whereas ET and CIMF revealed similar rates of mutation of about $60 \%$. No differences could be found between prefibrotic and manifest CIMF.

The high rate of JAK2 $2^{\mathrm{V} 617 \mathrm{~F}}$ and the high frequency of homozygous JAK2 status in PV give rise to the question whether this mutation represents a key event in PV genesis. In fact, JAK2 $2^{\mathrm{V} 617 \mathrm{~F}}$ is sufficient to mediate a PV-like phenotype in mouse models $[10,18,19]$. In ET patients, the presence of JAK2 ${ }^{\mathrm{V} 617 \mathrm{~F}}$ is associated with elevated levels of haemoglobin and haematocrit as well as increased bone marrow erythropoiesis and granulopoiesis [47-50]. Additionally, a small subset of JAK2 ${ }^{\mathrm{V} 617 \mathrm{~F}}$ ET patients even transform into manifest PV [47]. Consequently, it has been suggested that CMPD are better characterized as a phenotypical continuum with emphasis on different features and that JAK2 mutation status modulates rather than strictly separates entities [49]. With regard to the second aforementioned peculiarity, another surprising feature was observed in female cases of ET which were 
Table 1. Mutation frequencies in different myeloid and lymphoid entities

\begin{tabular}{|c|c|c|c|c|}
\hline & $\mathrm{JAK} 2^{\mathrm{V} 617 \mathrm{~F}} / \mathrm{n}$ & $\begin{array}{l}\text { Mutation } \\
\text { frequency }\end{array}$ & Reference & $\begin{array}{l}\text { Summation } \\
\text { of all data }\end{array}$ \\
\hline \multicolumn{5}{|l|}{ Myeloid disorders } \\
\hline PV & $\begin{array}{c}60 / 62 \\
71 / 73 \\
27 / 28 \\
58 / 63 \\
26 / 29 \\
40 / 45 \\
25 / 29 \\
58 / 72 \\
121 / 164 \\
83 / 128\end{array}$ & $\begin{array}{l}97 \%(70 \%+/+) \\
97 \% \\
96 \% \\
92 \%(21 \%+/+) \\
90 \% \\
89 \% \\
86 \% \\
81 \% \\
74 \%(25 \%+/+) \\
65 \%(27 \%+/+)\end{array}$ & $\begin{array}{l}\text { Lippert et al. [46] } \\
\text { Baxter et al. [13] } \\
\text { Horn et al. [30] } \\
\text { Tefferi et al. [47] } \\
\text { Bock et al. [31] } \\
\text { James et al. [10] } \\
\text { Jelinek et al. [17] } \\
\text { Jones et al. [15] } \\
\text { Levine et al. [16] } \\
\text { Kralovics et al. [14] }\end{array}$ & $569 / 693(82 \%)$ \\
\hline ET & $\begin{array}{c}45 / 60 \\
17 / 23 \\
29 / 51 \\
414 / 806 \\
73 / 130 \\
73 / 150 \\
9 / 21 \\
24 / 59 \\
37 / 115 \\
3 / 10 \\
4 / 15 \\
21 / 93\end{array}$ & $\begin{array}{l}75 \%(0 \%+/+) \\
74 \% \\
57 \% \\
53 \% \\
56 \%(6 \%+/+) \\
49 \% \\
43 \% \\
41 \% \\
32 \%(3 \%+/+) \\
30 \% \\
27 \% \\
23 \%(3 \%+/+)\end{array}$ & $\begin{array}{l}\text { Lippert et al. [46] } \\
\text { Horn et al., [30] } \\
\text { Baxter et al. [13] } \\
\text { Campbell et al. [11] } \\
\text { Antonioli et al. [48] } \\
\text { Wolanskyj et al. [50] } \\
\text { James et al. [10] } \\
\text { Jones et al. [15] } \\
\text { Levine et al. [16] } \\
\text { Jelinek et al. [17] } \\
\text { Bock et al. [31] } \\
\text { Kralovics et al. [14] }\end{array}$ & $749 / 1,533(49 \%)$ \\
\hline $\mathrm{Ph}^{-} \mathrm{CML}$ & $3 / 16$ & $19 \%$ & Jelinek et al. [17] & \\
\hline Chronic neutrophilic leukaemia & $\begin{array}{l}1 / 6 \\
\text { case report }\left(\mathrm{JAK} 2^{\mathrm{V} 617 \mathrm{~F}}\right) \\
\text { case report }\left(\mathrm{JAK} 2^{\mathrm{V} 617 \mathrm{~F}}\right)\end{array}$ & $17 \%$ & $\begin{array}{l}\text { Steensma et al. [23] } \\
\text { Mc Lornan et al. [24] } \\
\text { Lea et al. [25] }\end{array}$ & $3 / 8(38 \%)$ \\
\hline CMPD UC & $\begin{array}{c}13 / 52 \\
6 / 8\end{array}$ & $\begin{array}{l}25 \% \\
75 \%\end{array}$ & $\begin{array}{l}\text { Baxter et al. [13] } \\
\text { Horn et al. [30] }\end{array}$ & $19 / 60(32 \%)$ \\
\hline De novo AML & $\begin{array}{l}1 / 93 \\
0 / 28 \\
0 / 10\end{array}$ & $\begin{array}{l}1 \% \\
0 \% \\
0 \%\end{array}$ & $\begin{array}{l}\text { Levine et al. [16] } \\
\text { Jelinek et al. [17] } \\
\text { Bock et al. [31] }\end{array}$ & $1 / 131(<1 \%)$ \\
\hline Acute megakaryoblastic leukaemia & $2 / 11$ & $18 \%$ & Jelinek et al. [17] & \\
\hline AML from pre-existing CMPD & 3 case reports $\left(\mathrm{JAK} 2^{\mathrm{V} 617 \mathrm{~F}}\right)$ & & Levine et al. [16] & \\
\hline
\end{tabular}


Table 1 (continued)

\begin{tabular}{|c|c|c|c|c|}
\hline & $\mathrm{JAK} 2^{\mathrm{V} 617 \mathrm{~F}} / \mathrm{n}$ & $\begin{array}{l}\text { Mutation } \\
\text { frequency }\end{array}$ & Reference & $\begin{array}{l}\text { Summation } \\
\text { of all data }\end{array}$ \\
\hline MDS & $\begin{array}{l}5 / 101 \\
2 / 38 \\
2 / 48 \\
1 / 68\end{array}$ & $\begin{array}{l}5 \% \\
5 \% \\
4 \% \\
2 \%\end{array}$ & $\begin{array}{l}\text { Steensma et al. [23] } \\
\text { Ohyashiki et al. [26] } \\
\text { Levine et al. [16] } \\
\text { Jelinek et al. [17] }\end{array}$ & $10 / 255(4 \%)$ \\
\hline Juvenile myelomonocytic leukaemia & case report $\left(\mathrm{JAK} 2^{\mathrm{V} 617 \mathrm{~F}}\right)$ & & Tono et al. [28] & \\
\hline Systemic mastocytosis & $\begin{array}{l}2 / 8 \\
0 / 28\end{array}$ & $\begin{array}{r}25 \% \\
0 \%\end{array}$ & $\begin{array}{l}\text { Steensma et al. [23] } \\
\text { Jones et al. [15] }\end{array}$ & $2 / 36(6 \%)$ \\
\hline T cell acute lymphoblastic leukaemia & $0 / 93$ & $0 \%$ & Levine et al. [29] & \\
\hline B cell chronic lymphocytic leukaemia & $0 / 45$ & $0 \%$ & Levine et al. [29] & \\
\hline
\end{tabular}

concomitantly studied for X-chromosome inactivation patternsandJAK2 $2^{\mathrm{V} 617 \mathrm{~F}}$. Theydisplayedboth the JAK2 ${ }^{\mathrm{V} 617 \mathrm{~F}}$ mutation and polyclonality of granulocytes and platelets [51]. Obviously in these cases the JAK2 ${ }^{\mathrm{V} 617 \mathrm{~F}}$ clone did not have the potency to overgrow polyclonal haematopoiesis. Similar observations were made by Kralovics et al. [52] who found that the percentage of granulocytes and platelets with JAK2 ${ }^{\mathrm{V} 617 \mathrm{~F}}$ was often markedly lower than the percentage of clonal granulocytes determined by IDS or MPP1 clonality assays. The presence of JAK2 in only a subfraction of clonal cells was confirmed in 2 samples with $20 \mathrm{q}$ deletions as an autosomal, X-chromosome-independent clonality marker. From these results it was concluded that in a proportion of patients with CMPD, JAK $2^{\mathrm{V} 617 \mathrm{~F}}$ occurs on the background of clonal haematopoiesis caused by a somatic mutation in an as-yet-unknown gene [52]. Very low JAK2 ${ }^{\mathrm{V} 617 \mathrm{~F}}$ allele frequencies of $<10 \%$ are possible [34], but the biological significance remains elusive.

From these findings it emerges that diversity of $\mathrm{Ph}^{-}$and JAK2 $2^{\mathrm{V} 617 \mathrm{~F}}$-mutated CMPD could be either due to a combination with other clonal and more specific defects or to different gene dosages and lineage involvement by $\mathrm{JAK} 2^{\mathrm{V} 617 \mathrm{~F}}$. In order to investigate the latter hypotheses we conducted a study on allele frequency in bone marrow trephines from CMPD using pyrosequencing. The majority of PV and fibrotic CIMF exhibited allele frequencies of more than 50\%, suggesting homozygosity. In ET and prefibrotic CIMF, most cases exhibited heterozygosity with allele frequencies below 50\%. Because gene dosages may also be influenced by the rate of transcription, we quantified JAK2 ${ }^{\mathrm{V} 617 \mathrm{~F}}$ transcripts in ET and prefibrotic CIMF. Although the percentage of mutant $\mathrm{T}$ allele was constantly higher in cDNA than DNA, no differences could be noted between the 2 entities (unpublished data).

For the investigation of lineage involvement we purified megakaryocytes from bone marrow sections because atypical megakaryocytes provide a hallmark of most CMPD. The allele frequency in purified megakaryocytes was compared to that in the residual bone marrow purified from megakaryocytes [42]. With regard to homoand heterozygosity, similar results were obtained in purified megakaryocytes compared to the complete cellularity with the exception of ET. In 25\% of the ET cases the $\mathrm{JAK} 2^{\mathrm{V} 617 \mathrm{~F}}$ allele frequency in isolated megakaryocytes exceeded that of the non-megakaryocytic bone marrow cells by more than 2 -fold [42]. In about a quarter of the ET cases more than $50 \%$ of the megakaryocytic alleles were affected corresponding to homozygosity at least in a subfraction of the megakaryocytes [42]. 
Another question is the relationship of JAK2 ${ }^{\mathrm{V} 617 \mathrm{~F}}$ to fibrotic progression. In isolated megakaryocytes from manifest CIMF, more homozygous mutations were found than in cells isolated from prefibrotic cases (60\% vs. $33 \%$ ) [42] and homozygosity is associated with a higher risk of fibrotic transformation in PV [46]. Sequential biopsies derived from cases with fibrotic progression of cellular CIMF, however, did not show an association between gene dosage and onset of fibrosis [42]. Furthermore, among more than 80 CIMF cases with sequential biopsies not a single case was encountered with newly occurring $\mathrm{JAK} 2^{\mathrm{V} 617 \mathrm{~F}}$ (own unpublished data) which could have been expected according to the findings of Kralovics et al. [52]. Because the JAK/STAT signalling pathway is involved in the regulation of genes encoding matrix metalloproteinases (MMP), we examined the expression of MMP, their tissue inhibitors and collagen types in relation to the JAK2 status (V617F mutation versus wild-type) in CIMF. Whereas no correlation was found between the JAK2 mutation status and MMP gene products, there was an evident association of the latter with the stage of disease [52].

Whereas JAK2 analysis appears to be of little help in the classification of $\mathrm{Ph}^{-} \mathrm{CMPD}$ and prediction of fibrotic progression, an important application in routine diagnosis is obviously the verification of a neoplastic haematological disorder and discrimination from reactive erythrocytosis or thrombocytosis. Analysis can be available within few days and has proved to be very helpful e.g. in Budd-Chiari syndrome [54, 55]. Furthermore, the dogma that elevated serum EPO levels in Budd-Chiari syndrome patients exclude the diagnosis of $\mathrm{PV}$ is no longer supportable, since in a proportion of these patients the JAK $2 \mathrm{mu}$ tation was detectable [55].

The JAK2 status in CMPD patients interferes, if not with the histopathological manifestation, with the clinical course; more complications have been implied in $\mathrm{JAK} 2^{\mathrm{V} 617 \mathrm{~F}}$ cases, such as secondary fibrosis, haemorrhage and thrombosis, and these patients have received cytoreductive treatment more often than JAK2 wild-type patients [15]. Homozygously mutated PV patients revealed higher levels of haemoglobin and greater risk of fibrotic transformation than heterozygous patients [47]. CIMF patients harbouring the mutation were demonstrated to have shorter survival [56], and JAK2 ${ }^{\mathrm{V} 617 \mathrm{~F}}$ ET cases showed higher tendency for polycythemia, thrombosis, leukocytosis and advanced age at diagnosis $[48,50,57]$. With regard to chemosensitivity, JAK2 ${ }^{\mathrm{V} 617 \mathrm{~F}}$ ET patients seemed to have more benefit from hydroxyurea treatment than wild-type JAK2 patients, whereas such an effect was not obvious in patients receiving anagrelide [49]. This issue is of potential interest and needs more randomized trials including JAK2 mutation status as one of the study criteria. Moreover, strictly applied WHO criteria for classification of $\mathrm{Ph}^{-} \mathrm{CMPD}$ subtypes, along with the most reliable tests for detection of a potentially underlying JAK2 mutation, are indispensable for a correct estimation of response rates in studies conducted to determine the efficacy of therapeutic regimes.

It was questionable which role the JAK2 mutation might play in the worst biological end-stage of CMPD, namely the transformation into acute leukaemia [15]. Therefore, 42 CIMF patients with leukaemic transformation were analysed for JAK2 mutation status and prognostic correlations, but besides younger age and shorter interval to leukaemic transformation no differences in survival were observed [58]. However, more future studies are required to verify the role of JAK2 status as a prognostic marker.

\section{Summary}

The discovery of the JAK2 ${ }^{\mathrm{V} 617 \mathrm{~F}}$ mutation in the majority of $\mathrm{Ph}^{-} \mathrm{CMPD}$ is comparable to the breakthrough enabled by the detection of the BCR/ABL fusion gene. Since its discovery in 2005 the new molecular marker rapidly found its way into clinical diagnostics. Whereas it is very useful in discriminating neoplastic from reactive myeloproliferations, it appears to be of little help in subtyping of CMPD and prediction of fibrotic progression. The $\mathrm{JAK} 2^{\mathrm{V} 617 \mathrm{~F}}$ abnormality most likely acts in concert with other clonal and yet unknown molecular defects, and modifies the clinical course rather than determines the histopathological subtype of $\mathrm{Ph}^{-} \mathrm{CMPD}$. Higher proportions of homozygously mutated cases are found in PV and fibrotic CIMF than in ET and prefibrotic CIMF, but in individual follow-up studies fibrotic progression could not be linked to an increase in gene dosage. In ET the megakaryocytic lineage can be selectively or predominantly affected by the mutation.

\section{Acknowledgements}

This study was supported by DFG (Bo 1954/1-1) and Deutsche Krebshilfe (10-2191-Bo 1). 


\section{References}

1 Jaffe SS, Harris NL, Sterm A, Vardiman JW: WHO Classification of Tumours: Tumours of Haematopoiesis and Lymphoid Tissues. Lyon, IARC, 2001, pp 31-42.

2 Heuck G: Zwei Fälle von Leukämie mit eigentümlichem Blut resp. Knochenmarksbefund. Virchows Arch 1879;78:475.

3 Dameshek W: Some speculations on the myeloproliferative syndromes. Blood 1951;6: 372-375.

4 Dameshek W: Physiopathology and course of polycythemia vera as related to therapy. J Am Med Assoc 1950;142:790-797.

5 Berlin NI: Diagnosis and classification of the polycythemias. Semin Hematol 1975;12: 339-351.

6 Thiele J, Kvasnicka HM, Diehl V: Initial (latent) polycythemia vera with thrombocytosis mimicking essential thrombocythemia. Acta Haematol 2005;113:213-219.

-7 Kreft A, Büsche G, Ghalibafian M, Buhr T, Fischer T, Kirkpatrick CJ: The incidence of myelofibrosis in essential thrombocythaemia, polycythaemia vera and chronic idiopathic myelofibrosis: a retrospective evaluation of sequential bone marrow biopsies. Acta Haematol 2005;113:137-143.

$>8$ de Klein A, van Kessel AG, Grosveld G, Bartram CR, Hagemeijer A, Bootsma D, Spurr NK, Heisterkamp N, Groffen J, Stephenson JR: A cellular oncogene is translocated to the Philadelphia chromosome in chronic myelocytic leukaemia. Nature 1982;300:765-767.

$\checkmark 9$ Nowell PC, Hungerford DA: Chromosome studies on normal and leukemic leukocytes. J Natl Cancer Inst 1960;25:85-109.

10 James C, Ugo V, Le Couedic JP, Staerk J, Delhommeau F, Lacout C, Garcon L, Raslova H, Berger R, Bennaceur-Griscelli A, Villeval JL, ConstantinescuSN, CasadevallN, Vainchenker W: A unique clonal JAK2 mutation leading to constitutive signalling causes polycythaemia vera. Nature 2005;434:1144-1148.

-11 Campbell PJ, Scott LM, Baxter EJ, Bench AJ, Green AR, Erber WN: Acquired mutation of the tyrosine kinase in human myeloproliferative disorders. Lancet 2005;365:10541061.

12 Zhao R, Xing S, Li Z, Fu X, Li Q, Krantz SB, Zhao ZJ: Identification of an acquired JAK2 mutation in polycythemia vera. J Biol Chem 2005;280:22788-22792.

13 Baxter EJ, Scott LM, Campbell PJ, East C, Fourouclas N, Swanton S, Vassiliou GS, Bench AJ, Boyd EM, Curtin N, Scott MA, Erber WN, Green AR; Cancer Genome Project: Acquired mutation of the tyrosine kinase JAK2 in human myeloproliferative disorders. Lancet 2005;365:1054-1061.

- 14 Kralovics R, Passamonti F, Buser AS, Teo SS, Tiedt R, Passweg JR, Tichelli A, Cazzola M, Skoda RC: A gain-of-function mutation of JAK2 in myeloproliferative disorders. $\mathrm{N}$ Engl J Med 2005;352:1779-1790.
15 Jones AV, Kreil S, Zoi K, Waghorn K, Curtis C, Zhang L, Score J, Seear R, Chase AJ, Grand FH, White H, Zoi C, Loukopoulos D, Terpos E, Vervessou EC, Schultheis B, Emig M, Ernst T, Lengfelder E, Hehlmann R, Hochhaus A, Oscier D, Silver RT, Reiter A, Cross NC: Widespread occurrence of the JAK2 V617F mutation in chronic myeloproliferative disorders. Blood 2005; 106:2162-2168.

16 Levine RL, Wadleigh M, Cools J, Ebert BL, Wernig G, Huntly BJ, Boggon TJ, Wlodarska I, Clark JJ, Moore S, Adelsperger J, Koo S, Lee JC, Gabriel S, Mercher T, D’Andrea A, Frohling S, Dohner K, Marynen P, Vandenberghe P, Mesa RA, Tefferi A, Griffin JD, Eck MJ, Sellers WR, Meyerson M, Golub TR, Lee SJ, Gilliland DG: Activating mutation in the ty rosine kinase JAK2 in polycythemia vera, es sential thrombocythemia and myeloid metaplasia with myelofibrosis. Cancer Cell 2005; 7:387-397.

17 Jelinek J, Oki Y, Gharibyan V, Bueso-Ramos C, Prchal JT, Verstovsek S, Beran M, Estey E Kantarjian HM, Issa JP: JAK2 mutation $1849 \mathrm{G}>\mathrm{T}$ is rare in acute leukemias but can be found in CMML, Philadelphia chromosome-negative CML, and megakaryocytic leukemia. Blood 2005;106:3370-3373.

18 Lacout C, Pisani DF, Tulliez M, Moreau Gachelin F, Vainchenker W, Villeval JL: JAK2V617F expression in murine hematopoietic cells leads to MPD mimicking human PV with secondary myelofibrosis. Blood 2006;108:1652-1660

19 Wernig G, Mercher T, Okabe R, Levine RL, Lee $\mathrm{BH}$, Gilliland DG: Expression of Jak2V617F causes a polycythemia vera-like disease with associated myelofibrosis in a murine bone marrow transplant model. Blood 2006;107:4274-4281.

20 Luo H, Rose P, Barber D, Hanratty WP, Lee S, Roberts TM, D’Andrea AD, Dearolf CR Mutation in the Jak kinase JH2 domain hyperactivates Drosophila and mammalian Jak-Stat pathways. Mol Cell Biol 1997;17: 1562-1571.

21 Cools J, Peeters P, Voet T, Aventin A, Mecucci C, Grandchamp B, Marynen P: Genomic organization of human JAK2 and mutation analysis ofits JH2-domaininleukemia Cytogenet Cell Genet 1999;85:260-266.

22 Quentmeier H, MacLeod RA, Zaborski M, Drexler HG: JAK2 V617F tyrosine kinase mutation in cell lines derived from myeloproliferative disorders. Leukemia 2006;20: 471-476.

23 Steensma DP, Dewald GW, Lasho TL, Powell HL, McClure RF, Levine RL, Gilliland DG, Tefferi A: The JAK2 V617F activating tyrosine kinase mutation is an infrequent event in both 'atypical' myeloproliferative disorders and myelodysplastic syndromes. Blood 2005;106:1207-1209.
24 Mc Lornan DP, Percy MJ, Jones AV, Cross NC, Mc Mullin MF: Chronic neutrophilic leukemia with an associated V617F JAK2 tyrosine kinase mutation. Haematologica 2005;90:1696-1697.

25 Lea NC, Lim Z, Westwood NB, Arno MJ, Gäken J, Mohamedali A, Mufti GJ: Presence of JAK2 V617F tyrosine kinase mutation as a myeloid-lineage-specific mutation in chronic neutrophilic leukaemia. Leukemia 2006; 20:1324-1326.

26 Ohyashiki K, Aota Y, Akahane D, Gotoh A, Miyazawa K, Kimura Y, Ohyashiki JH: The JAK2 V617F tyrosine kinase mutation in myelodysplastic syndromes (MDS) developing myelofibrosis indicates the myeloproliferative nature in a subset of MDS patients. Leukemia 2005;19:2359-2360.

27 Johan MF, Goodeve AC, Bowen DT, Frew ME, Reilly JT: JAK2 V617F Mutation is uncommon in chronic myelomonocytic leukaemia. Br J Haematol 2005;130:968.

28 Tono C, Xu G, Toki T, Takahashi Y, Sasaki S, Terui K, Ito E: JAK2 Val617Phe activating tyrosine kinase mutation in juvenile myelomonocytic leukemia. Leukemia 2005;19: 1843-1844

29 Levine RL, Loriaux M, Huntly BJ, Loh ML, Beran M, Stoffregen E, Berger R, Clark JJ, Willis SG, Nguyen KT, Flores NJ, Estey E, Gattermann N, Armstrong S, Look AT, Griffin JD, Bernard OA, Heinrich MC, Gilliland DG, Druker B, DeiningerMW: The JAK2 $2^{\text {V617F }}$ activating mutation occurs in chronic myelomonocytic leukemia and acute myeloid leukemia, but not in acute lymphoblastic leukemia or chronic lymphocytic leukemia. Blood 2005; 106:3377-3379.

30 Horn T, Kremer M, Dechow T, Pfeifer WM, Geist B, Perker M, Duyster J, QuintanillaMartinez L, Fend F: Detection of the activating JAK2 V617F mutation in paraffin-embedded trephine bone marrow biopsies of patients with chronic myeloproliferative diseases. J Mol Diagn 2006;8:299-304

31 Bock O, Busche G, Koop C, Schroter S, Buhr T, Kreipe H: Detection of the single hotspot mutation in the $\mathrm{JH} 2$ pseudokinase domain of Janus kinase 2 in bone marrow trephine biopsies derived from chronic myeloproliferative disorders. J Mol Diagn 2006;8:170-177.

32 Kralovics R, Teo SS, Buser AS, Brutsche M, Tiedt R, Tichelli A, Passamonti F, Pietra D, Cazzola M, Skoda RC: Altered gene expression in myeloproliferative disorders correlates with activation of signaling by the V617F mutation of Jak2. Blood 2005;106: 3374-3376.

33 Lu X, Levine R, Tong W, Wernig G, Pikman Y, Zarnegar S, Gilliland DG, Lodish H: Expression of a homodimeric type I cytokine receptor is required for JAK2V617F-mediated transformation. Proc Natl Acad Sci USA 2005;102:18962-18967. 
-34 Ishii T, Bruno E, Hoffman R, Xu M: Involvement of various hematopoietic cell lineages by the JAK $2^{\mathrm{V} 617 \mathrm{~F}}$ mutation in polycythemia vera. Blood 2006;108;3128-3134.

35 Bock O, Hussein K, Brakensiek K, Buhr T, Schlué J, Wiese B, Kreipe H: The Suppressor of Cytokine Signalling -1 (SOCS-1) gene is overexpressed in Philadelphia chromosome negative chronic myeloproliferative disorders. Leuk Res 2006, E-pub ahead of print.

>36 Bock O, Hussein K, Neusch M, Schlué J, Wiese B, Kreipe H: Transcription factor Fli-1 expression by bone marrow cells in chronic myeloproliferative disorders is independent of an underlying JAK2 (V617F) mutation. Eur J Haematol 2006;77:463-470.

-37 Lasho TL, Mesa R, Gilliland DG, Tefferi A: Mutation studies in $\mathrm{CD} 3+, \mathrm{CD} 19+$ and CD34+ cell fractions in myeloproliferative disorders with homozygous JAK2 $2^{\mathrm{V} 617 \mathrm{~F}}$ in granulocytes. Br J Haematol 2005;130:797799.

38 Jamieson CH, Gotlib J, Durocher JA, Chao MP, Mariappan MR, Lay M, Jones C, Zehnder JL, Lilleberg SL, Weissman IL: The JAK2 V617F mutation occurs in hematopoietic stem cells in polycythemia vera and predisposes toward erythroid differentiation. Proc Natl Acad Sci USA 2006;103:6224-6229.

39 Delhommeau F, Dupont S, Tonetti C, Masse A, Godin I, Le Couedic JP, Debili N, Saulnier P, Casadevall N, Vainchenker W, Giraudier S. Evidence that the JAK2 G1849T (V617F) mutation occurs in a lympho-myeloid progenitor in polycythemia vera and idiopathic myelofibrosis. Blood 2006, E-pub ahead of print.

40 Hussein K, Brakensiek K, Ballmaier M, Bormann M, Göhring G, Buhr T, Bock O, Kreipe $\mathrm{H}$ : B-CLL developing in a patient with $\mathrm{PV}$ is not affected by V617F mutation of the Janus kinase 2. Eur J Haematol, 2006;77:539-541.

-41 Zehentner BK, Loken MR, Wells DA: $\mathrm{JAK} 2^{\mathrm{V} 617 \mathrm{~F}}$ mutation can occur exclusively in the erythroid lineage and be absent in granulocytes and progenitor cells in classic myeloproliferative disorders. Am J Hematol 2006; 81:806-807.

-42 Hussein K, Brakensiek K, Buesche G, Buhr T, Wiese B, Kreipe H, Bock O: Different involvement of the megakaryocytic lineage by the JAK2 $2^{\mathrm{V} 617 \mathrm{~F}}$ mutation in polycythemia vera, essential thrombocythemia and chronic idiopathic myelofibrosis. Ann Hematol 2007;86:245-253.
43 Pardanani AD, Levine RL, Lasho T, Pikman Y, Mesa RA, Wadleigh M, Steensma DP, Elliott MA, Wolanskyj AP, Hogan WJ, Mc Clure RF, Litzow MR, Gilliland DG, Tefferi A: MPL515 mutations in myeloproliferative and other myeloid disorders: a study of 1182 patients. Blood 2006;108:3472-3476.

44 Pikman Y, Lee BH, Mercher T, McDowell E, Ebert BL, Gozo M, Cuker A, Wernig G, Moore S, Galinsky I, Deangelo DJ, Clark JJ Lee SJ, Golub TR, Wadleigh M, Gilliland DG, Levine RL: MPLW515L is a novel somatic activating mutation in myelofibrosis with myeloid metaplasia. PLoS Med 2006;3:e270.

45 Murugesan G, Aboudola S, Szpurka H, Verbic MA, Maciejewski JP, Tubbs RR, Hsi ED Identification of the JAK2 V617F mutation in chronic myeloproliferative disorders us ing FRET probes and melting curve analysis Am J Clin Pathol 2006;125:651-653.

46 Lippert E, Boissinot M, Kralovics R, Girodon F, Dobo I, Praloran V, Boiret-Dupre N, Skoda RC, Hermouet S: The JAK2-V617F mutation is frequently present at diagnosis in patients with essential thrombocythemia and polycythemia vera. Blood 2006;108:1865-1867.

47 Tefferi A, Lasho TL, Schwager SM, Strand JS Elliott M, Mesa R, Li CY, Wadleigh M, Lee SJ, Gilliland DG: The clinical phenotype of wild-type, heterozygous, and homozygous JAK2V617F in polycythemia vera. Cancer 2006;106:631-635.

48 Antonioli E, Guglielmelli P, Pancrazzi A, Bogani C, Verruci M, Ponziani V, Longo G, Bosi A, Vannucchi AM: Clinical implications of the JAK2 V617F mutation in essential thrombocythaemia. Leukaemia 2005;19:18471849 .

49 Campbell PJ, Scott LM, Buck G, Wheatley K, East CL, Marsden JT, Duffy A, Boyd EM, Bench AJ, Scott MA, Vassiliou GS, Milligan DW, Smith SR, Erber WN, Bareford D, Wilkins BS, Reilly JT, Harrison CN, Green AR: Definition of subtypes of essential thrombocythaemia and relation to polycythaemia vera based on JAK2 V617F mutation status: a prospective study. Lancet $2005 ; 366$ 1945-1953.

50 Wolanskyj AP, Lasho TL, Schwager SM, McClure RF, Wadleigh M, Lee SJ, Gilliland DG, Tefferi A: JAK2 mutation in essential thrombocythaemia: clinical associations and longterm prognostic relevance. Br J Haematol 2005;131:208-213.
51 Kiladjian JJ, Elkassar N, Cassinat B, Hetet G, Giraudier S, Balitrand N, Conejero C, Briere J, Fenaux P, Chomienne C, Grandchamp B: Essential thrombocythemias without V617F JAK2 mutation are clonal hematopoietic stem cell disorders. Leukemia 2006;20:11811183.

52 Kralovics R, Teo SS, Li S, Theocharides A, Buser AS, Tichelli A, Skoda RC: Acquisition of the V617F mutation of JAK2 is a late genetic event in a subset of patients with myeloproliferative disorders. Blood 2006;108: 1377-1380.

53 Bock O, Neuse J, Hussein K, Brakensiek K, Buesche G, Buhr T, Wiese B, Kreipe H: Aberrant collagenase expression in chronic idiopathic myelofibrosis is related to the stage of disease but not to the JAK2 mutation status. Am J Pathol 2006;169:471-481.

54 Patel RK, Lea NC, Heneghan MA, Westwood NB, Milojkovic D, Thanigaikumar M, Yallop D, Arya R, Pagliuca A, Gaken J, Wendon J, Heaton ND, Mufti GJ: Prevalence of the activating JAK2 tyrosine kinase mutation V617F in the Budd-Chiari syndrome. Gastroenterology 2006;130:2031-2038.

55 Thurmes PJ, Steensma DP: Elevated serum erythropoietin levels in patients with BuddChiari syndrome secondary to polycythemia vera: clinical implications for the role of JAK2 mutation analysis. Eur J Haematol 2006;77:57-60

56 Campbell PJ, Griesshammer M, Dohner K, Dohner H, Kusec R, Hasselbalch HC, Larsen TS, Pallisgaard N, Giraudier S, Le BousseKerdiles MC, Desterke C, Guerton B, Dupriez B, Bordessoule D, Fenaux P, Kiladjian JJ, Viallard JF, Briere J, Harrison CN, Green AR, Reilly JT: V617F mutation in JAK2 is associated with poorer survival in idiopathic myelofibrosis. Blood 2006;107:2098-2100.

57 Cheung B, Radia D, Pantelidis P, Yadegarfar G, Harrison C: The presence of the JAK2 V617F mutation is associated with a higher haemoglobin and increased risk of thrombosis in essential thrombocythaemia. $\mathrm{Br} \mathrm{J} \mathrm{Hae-}$ matol 2006;132:244-245.

58 Mesa RA, Powell H, Lasho T, Dewald G, McClure R, Tefferi A: JAK2 ${ }^{\mathrm{V} 617 \mathrm{~F}}$ and leukemic transformation in myelofibrosis with myeloid metaplasia. Leuk Res 2006;30:14571460 . 